\title{
Blue nails: window to micronutrient deficiency
}

\author{
Lesa Dawman, ${ }^{1}$ Indar Kumar Sharawat, ${ }^{1}$ Keshavamurthy Vinay ${ }^{2}$
}

${ }^{1}$ Department of Pediatrics, Post Graduate Institute of Medical Education and Research, Chandigarh, India ${ }^{2}$ Department of Dermatology, Post Graduate Institute of Medical Education and Research, Chandigarh, India

\section{Correspondence to}

Dr Lesa Dawman, lesadawman@gmail.com

Accepted 9 February 2018

\section{Check for updates}

To cite: Dawman $\mathrm{L}$, Sharawat IK, Vinay K. BMJ Case Rep Published Online First: [please include Day Month Year]. doi:10.1136/ bcr-2018-224258

\section{DESCRIPTION}

A 12-year-old boy presented with progressive darkening of nails of both hands and feet for the past 3 months. He noticed the blue-black pigmentation of all the fingernails and toenails (figure 1A,B). Pigmentation was more marked in fingernails, particularly over thumbnails (figure 1C,D). The pigmentation started proximally and progressed distally. It was associated with hyperpigmentation of distal phalanges and nail bed. There was no history of any exposure to dyes or work in factory, trauma or exposure to any other agents. There was no history of dermatitis or rash prior to this complaint. He was a non-vegetarian. Other systemic examination was unremarkable.

Lab investigations revealed macrocytic hypochromic anaemia (haemoglobin $10.9 \mathrm{~g} / \mathrm{dL}$, mean corpuscular volume $110 \mathrm{fL}$ ), decreased serum vitamin $B_{12}(80.61 \mathrm{pg} / \mathrm{mL})$, normalserumfolatelevels $(4.8 \mathrm{ng} / \mathrm{mL})$, elevated serum homocysteine level $(55.47 \mu \mathrm{mol} / \mathrm{L})$ and mildly elevated urinary methyl malonic acid. His serum adrenocorticotropin hormone level was within normal limits. The severe vitamin $B_{12}$ deficiency was considered as the attributing factor for his nail hyperpigmentation. He was started on daily intramuscular vitamin $B_{12}$ therapy $(1 \mathrm{mg} /$ day) for 7 days followed by weekly injections for 4 weeks along with oral $\mathrm{B}_{12}(1 \mathrm{mg} /$ day $)$ and other micronutrients. Serum homocysteine became normal after 1 month of therapy $(6.4 \mu \mathrm{mol} / \mathrm{L})$.

The clinical manifestations of vitamin $\mathrm{B}_{12}$ deficiency are megaloblastic anaemia, glossitis and neurological symptoms like sensory abnormalities, tremors and psychiatric symptom. ${ }^{1}$ Other less

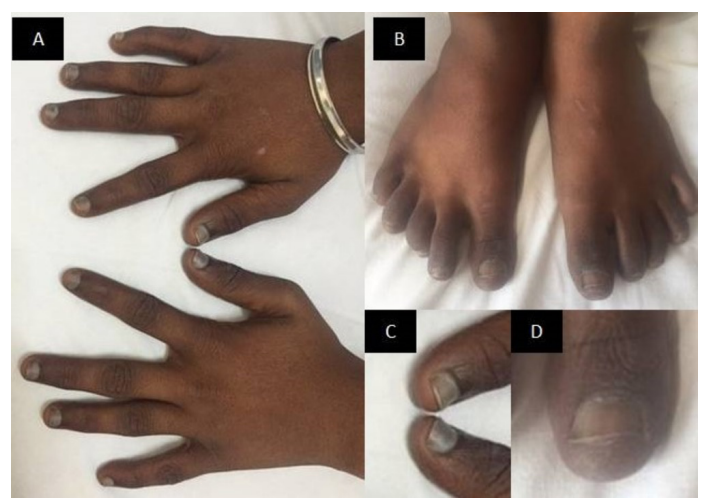

Figure 1 Hyperpigmentation of nails. Blue-black pigmentation of all the fingernails and toenails $(A, B)$ with associated hyperpigmentation of nail bed, distal phalanges and knuckles. It is more marked on thumbs and great toes $(C, D)$.

\section{Learning points}

- Possibility of $B_{12}$ deficiency should be considered in case of unexplained pigmentation.

- Vitamin $\mathrm{B}_{12}$ deficiency mimicking Addison pigmentation should be ruled out.

- Early diagnosis and prompt treatment can cause the reversal of symptoms.

common features are cutaneous hyperpigmentation, aphthous stomatitis, cheilitis, vitiligo, sparse lusterless hypopigmented hairs and blue-black pigmentation of nails. ${ }^{2}$ Nail changes in vitamin $B_{12}$ deficiency present as hyperpigmentation of nails like bluish discoloration of nails, blue-black pigmentation with dark longitudinal streaks, and longitudinal and reticulate darkened streaks. The nail pigmentation associated with $\mathrm{B}_{12}$ deficiency is more frequent in patients with dark skin. The mechanism of hyperpigmentation is proposed to be decreased glutathione levels resulting in disinhibition of tyrosinase, an enzyme of melanogenesis leading to increased melanin synthesis. ${ }^{3}$ The cutaneous manifestations can be reversed with $B_{12}$ therapy. Possibility of vitamin $B_{12}$ deficiency should be kept in a patient presenting with only cutaneous manifestation of hyperpigmentation. Complications of vitamin $\mathrm{B}_{12}$ deficiency may be prevented if the condition is recognised early and treatment is initiated.

Contributors LD: clinician in charge, concept and design of the study, initial draft manuscript preparation, critical review of manuscript, final approval of the version to be published. IKS: patient management, literature review, initial draft manuscript preparation. KV: critical review of manuscript, literature review, final approval of the version to be published.

Funding This research received no specific grant from any funding agency in the public, commercial or not-for-profit sectors.

Competing interests None declared.

Patient consent Not required.

Provenance and peer review Not commissioned; externally peer reviewed.

(C) BMJ Publishing Group Ltd (unless otherwise stated in the text of the article) 2018. All rights reserved. No commercial use is permitted unless otherwise expressly granted.

\section{REFERENCES}

1 Demir N, Doğan M, KoçA, et al. Dermatological findings of vitamin B12 deficiency and resolving time of these symptoms. Cutan Ocul Toxicol 2014;33:70-3.

2 Niiyama S, Mukai H. Reversible cutaneous hyperpigmentation and nails with white hair due to vitamin B12 deficiency. Eur J Dermatol 2007; 17:551-2.

3 Mori K, Ando I, Kukita A. Generalized hyperpigmentation of the skin due to vitamin B12 deficiency. J Dermatol 2001;28:282-5. 
Copyright 2018 BMJ Publishing Group. All rights reserved. For permission to reuse any of this content visit http://group.bmj.com/group/rights-licensing/permissions.

BMJ Case Report Fellows may re-use this article for personal use and teaching without any further permission.

Become a Fellow of BMJ Case Reports today and you can:

- Submit as many cases as you like

- Enjoy fast sympathetic peer review and rapid publication of accepted articles

Access all the published articles

- Re-use any of the published material for personal use and teaching without further permission

For information on Institutional Fellowships contact consortiasales@bmjgroup.com

Visit casereports.bmj.com for more articles like this and to become a Fellow 